\title{
Effect of Foliar Applied Urea on Growth and Yield of Sunflower (Helianthus annuus L.)
}

\author{
Rajesh Kumar Oad, Muhammad Ali Ansari, Jagdesh Kumar, Dilpat Rai Menghwar* \\ Department of Agronomy, Faculty of Crop Production, Sindh Agriculture University, Hyderabad, Pakistan \\ Email: ^rai48_sau@yahoo.com
}

How to cite this paper: Oad, R.K., Ansari, M.A., Kumar, J. and Menghwar, D.R. (2018) Effect of Foliar Applied Urea on Growth and Yield of Sunflower (Helianthus annuus L.). Open Access Library Journal, 5: e4668.

https://doi.org/10.4236/oalib.1104668

Received: May 18, 2018

Accepted: July 10, 2018

Published: July 13, 2018

Copyright $\odot 2018$ by authors and Open Access Library Inc.

This work is licensed under the Creative Commons Attribution International License (CC BY 4.0).

http://creativecommons.org/licenses/by/4.0/

\begin{abstract}
A field study was carried out during 2012-13 at Sindh Agriculture University, Tandojam, Pakistan, geographically latitude $25^{\circ} \mathrm{N}$ and longitude $68^{\circ} \mathrm{E}$, to assess the effect of foliar applied urea on the growth and yield of sunflower. The experiment was laid out in a three-replicated Randomized Complete Block Design. Five treatments were tested against sunflower variety Hysun-33 which included: $\mathrm{T}_{1}=$ Control (no urea), $\mathrm{T}_{2}=$ Recommended urea soil applied (130 $\mathrm{kg} \cdot \mathrm{ha}^{-1}$ ) at sowing stage, $\mathrm{T}_{3}=1 \%$ urea at 35 days after sowing, $\mathrm{T}_{4}=1 \%$ urea at 60 days after sowing and $\mathrm{T}_{5}=1 \%$ urea at 85 days after sowing. The results revealed that growth and yield characters as well as oil yield of sunflower were significantly $(\mathrm{P}<0.05)$ affected by foliar application of urea. The most effective treatment comprised of foliar application of urea (1\%) after 35 days of sowing in addition to recommended soil applied urea $\left(130 \mathrm{~kg} \cdot \mathrm{ha}^{-1}\right)$ showed optimistic results with $89.61 \%$ seed germination, $179.65 \mathrm{~cm}$ plant height, 5.39 $\mathrm{cm}$ stem girth, $22.43 \mathrm{~cm}$ head diameter, 2063.25 grains head $^{-1}, 68.51 \mathrm{~g}$ seed index $/ 1000$ seed weight, $2211.90 \mathrm{~kg}$ seed yield $\mathrm{ha}^{-1}$ and $1046.75 \mathrm{~kg}$ oil yield $\mathrm{ha}^{-1}$. The sunflower crop receiving foliar application of urea after 60 days or 85 days of sowing in addition to recommended soil applied urea ranked $2^{\text {nd }}$ and $3^{\text {rd}}$; and sunflower plantation given no foliar urea and grown only on recommended soil applied urea $\left(130 \mathrm{~kg} \cdot \mathrm{ha}^{-1}\right)$ ranked $4^{\text {th }}$ with $1907.96 \mathrm{~kg} \cdot \mathrm{ha}^{-1}$ seed yield and $841.91 \mathrm{~kg} \cdot \mathrm{ha}^{-1}$ oil yield. However, sunflower plantation neither given foliar application of urea nor supplied with soil applied urea (control) ranked least for all the growth and yield parameters and oil yield. Hence, it is suggested for the farmers that in addition to $130 \mathrm{~kg} \cdot \mathrm{ha}^{-1}$ soil applied urea, foliar application of urea (1\%) after 35 days of sowing may be ensured for maximization of seed and oil yields in sunflower. The results further showed that in most cases, the crop receiving foliar application of urea after 60 and 85 days of sowing showed similarity $(\mathrm{P}>0.05)$; but differences were significant $(\mathrm{P}<0.05)$ when compared with foliar application after 35 days of sowing and rest of the treatments.
\end{abstract}




\section{Subject Areas}

Agricultural Science, Plant Science

\section{Keywords}

Foliar, Growth, Sunflower, Urea

\section{Introduction}

Sunflower (Helianthus annuus, L.) is a non-conventional oilseed crop having short growing season which completes its production cycle in 90 - 120 days and can be grown twice a year. It fits well in existing cropping systems and can be grown without replacing any major crop [1]. Among the crop producing edible oils, sunflower is a leading source of edible oils in the world and preferred due to high unsaturated fatty acids content [2]. Sunflower seed contains $25 \%-48 \%$ oil and $20 \%-27 \%$ protein. Its oil contains high percentage of poly-unsaturated fatty acids (60\%), accepted largely in diet to reduce cholesterol in blood and prevents heart diseases [3]. Sunflower oil is quite palatable and contains soluble vitamins $\mathrm{A}, \mathrm{D}, \mathrm{E}$ and $\mathrm{K}$. It is used in manufacturing of margarine; and sunflower cake is used as cattle feed [4].

Sunflower has the potential to bridge up the gap between demand and supply of edible oil and it is well adapted to agro-ecological conditions of Pakistan. During the year 2011-12, the total availability of edible oil was 2.748 million tons. Local production of edible oil is remained 0.636 million tons while imports were 2.148 million tons. The import bill during 2011-12 stood at Rs. 216.4 billion [5]. The literature indicates that efficient use of nitrogen fertilizer plays major role in successful crop production [6]. Foliar application of $\mathrm{N}$ in the form of urea has the advantages of low cost and rapid plant response [7]. Nitrogen is an essential element and important determinant in growth and development of crop plants. It has an important role in chlorophyll, protein, nucleic acid, hormones and vitamin synthesis and helps in cell division, cell elongation [6]. Similarly, foliar fertilization is very useful to fulfil the plant requirement for various macro and micronutrients. Foliar fertilizers immediately deliver nutrients to the tissues and organs of the crop. This is a practice of applying liquid fertilizers to leaves. The leaves are green factories where photosynthesis produces compounds needed for growth. These are absorbed right at the site they are used acting fast. For instance, 80 per cent of the phosphorus applied through conventional fertilizers may get fixed up in the soil but up to 80 per cent of the foliar-added phosphorus is directly absorbed. [8] reported foliar application of micronutrients along with straight soil applied NPK that maximized net returns to the growers; while [9] applied various concentrations of different organic and inorganic solutions in foliar form and reported enhanced crop growth and yield. Foliar application of $\mathrm{N}$ in the form of urea has the advantages of low cost and rapid plant 
response, and the disadvantage of possible foliar burn, incompatibility problems with other chemicals and limitations on the amount of nutrient that can be applied [7]. [10] found that supplemental foliar $\mathrm{N}$ applications resulted varied response depended on the location, due to differences in soil characteristics. [11] found that the response of foliar fertilization is associated with the soil and environmental conditions. Once foliar applied urea is absorbed by the leaves, it is converted to ammonia, by the enzyme urease [12], and ammonia is incorporated into glutamate by the enzyme glutamine synthetase [13]. The foliar application urea can be an effective method to help study the fate of urea in plant leaves. Keeping in view the facts stated above, the present study was carried out to investigate the effect of foliar applied urea on growth and yield of sunflower (Helianthus annuus L.) under agro-ecological conditions of Tandojam.

\section{Materials and Methods}

The experiment was carried out in a three replicated Randomized Complete Block Design at Latif farm Sindh Agriculture University Tandojam, Pakistan geographically latitude $25^{\circ} \mathrm{N}$ and longitude $68^{\circ} \mathrm{E}$. The plot size was maintained at $6 \mathrm{~m} \times 3 \mathrm{~m}\left(18 \mathrm{~m}^{2}\right)$. Five Treatments: $\mathrm{T}_{1}=$ Control (no urea), $\mathrm{T}_{2}=$ Recommended urea soil applied $\left(130 \mathrm{~kg} \cdot \mathrm{ha}^{-1}\right)$ at the time of sowing, $\mathrm{T}_{3}=1 \%$ urea at 35 days after sowing, $\mathrm{T}_{4}=1 \%$ urea at 60 days after sowing, $\mathrm{T}_{5}=1 \%$ urea at 85 days after sowing. The experimental land was prepared in off-season in the month of October to February 2012-2013, length of the crop was 130 day as and well worked by using disc plow, followed leveling. After soaking dose, the plots were given two plowings. The clods were crushed followed by planking for uniform distribution of seed, fertilizer and irrigation water. The seed of sunflower variety Hysun-33 was obtained with the courtesy of oilseeds Botanist, Agriculture Research Institute, Tandojam. The sowing of the crop was done by using single coulter hand drilling at row x plant spacing of $45 \times 30 \mathrm{~cm}$ on $2^{\text {nd }}$ October 2012 using seed rate of $10 \mathrm{~kg} \cdot \mathrm{ha}^{-1}$. In fertilizers, $\mathrm{N}$ was applied at the rate of 130 $\mathrm{kg} \cdot \mathrm{ha}^{-1}$ in three splits at the time of sowing, at $2^{\text {nd }}$ irrigation and at $3^{\text {rd }}$ irrigation in the form of Urea. In addition to soil applied $\mathrm{N}$, foliar spray of urea (1.0\%) was also applied as per the treatment plan. All P $\left(50 \mathrm{~kg} \cdot \mathrm{ha}^{-1}\right)$ and $\mathrm{K}\left(25 \mathrm{~kg} \cdot \mathrm{ha}^{-1}\right)$ along with $1 / 3^{\text {rd }}$ of $\mathrm{N}$ were applied at the time of sowing. Pest scouting was adopted to keep close eye on insect pest infestation. The observations were recorded on the following growth and yield contributing characters: Seed germination (\%), Plant height $(\mathrm{cm})$, Stem girth $(\mathrm{cm})$, Head diameter $(\mathrm{cm})$, Grains head ${ }^{-1}$, Seed index (1000 seed weight, $\mathrm{g})$, Grain yield $\left(\mathrm{kg} \cdot \mathrm{ha}^{-1}\right)$, Oil yield $\left(\mathrm{kg} \cdot \mathrm{ha}^{-1}\right)$. The observations on parameters were recorded on the basis of randomly selected four plants in each plot. These sample plants were labeled with certain coding and reading of the four plants was averaged for replication-wise data. The oil content was determined by oil expeller method in the laboratory of Soil Science Chemistry Department University of Sindh Jamshoro. The data collected on the certain growth and yield components were statistically analyzed by deriving analysis of 
variance to examine the overall significance of differences among treatment means as well as compared to control; while LSD (Least Significant Difference) test was applied to compare and perceive superiority of treatment means and observe significance of differences, following statistical methods suggested by Gomez and Gomez (1984). All these tests were performed by using Statix 8.1 Micro-Computer Statistical Software (USA).

\section{Results}

The effect of foliar applied urea on the growth and yield of sunflower (Helianthus annuus L.) was investigated in a three replicated Randomized Complete Block Design. Five treatments were examined against sunflower. The results on these traits of economic importance are presented in Table 1. The germination percentage in sunflower in response to varying nutrient management was recorded and the results are presented in Table 1 . The analysis of variance showed that the germination percentage of sunflower was significantly $(\mathrm{P}<0.05)$ influenced by foliar application of urea as compared to control. It is evident from the results that seed germination of sunflower variety Hysun-33 was highest $(90.40 \%)$ in plots treated with foliar application of urea at $1 \%$ concentration after 85 days of sowing, closely followed by average seed germination of 90.05, 89.61 and 89.13 percent observed in plots treated with foliar application of urea after 60 days of sowing, foliar application of urea after 35 days of sowing and soil application of recommended urea $\left(130 \mathrm{~kg} \cdot \mathrm{ha}^{-1}\right)$, respectively. However, the minimum seed germination of 76.84 percent was observed in control plots, where urea was applied neither through soil nor in foliar form. The results indicated that the influence of soil applied urea on seed germination was remarkable as compared to control; which necessitates the soil application of urea as basal dose for quick seed germination. However, there was no impact of foliar application of urea on seed germination as the differences in seed germination percentage between soil application of urea at recommended dose of $130 \mathrm{~kg} \cdot \mathrm{ha}^{-1}$ and foliar application of urea after 85, 60 and 35 days of sowing was statistically non-significant $(\mathrm{P}>0.05)$.

Plant height $(\mathrm{cm})$ : The results in regards to plant height of sunflower influenced by foliar application of urea are given in Table 2. The analysis of variance demonstrated that the effect of foliar application of urea on the plant height of sunflower was statistically significant $(\mathrm{P}<0.05)$. It is apparent from the results that the maximum plant height $(179.76 \mathrm{~cm})$ was recorded in sunflower crop given foliar application of urea (1\%) after 35 days of sowing, closely followed by foliar application of urea after 60 days and 85 days of sowing with average plant height of $177.95 \mathrm{~cm}$ and $174.65 \mathrm{~cm}$, respectively. In plots fertilized only by soil application of urea at $130 \mathrm{~kg} \cdot \mathrm{ha}^{-1}$ without foliar application of urea, the plant height reduced to $163.70 \mathrm{~cm}$; while the minimum plant height of $106.54 \mathrm{~cm}$ was observed in control, where urea was applied neither through soil nor in foliar form. It was noted that there was remarkable and positive impact of foliar application 
Table 1. Seed germination (\%) of sunflower as affected by soil application of urea.

\begin{tabular}{ccccc}
\hline Treatments & RI & RII & RIII & Mean \\
\hline $\mathrm{T}_{1}=$ Control (no urea) & 77.3 & 80.6 & 72.5 & 76.8 \\
$\mathrm{~T}_{2}=$ Recommended urea soil applied $\left(130 \mathrm{~kg} \cdot \mathrm{ha}^{-1}\right)$ & 91.6 & 88.5 & 87.1 & 89.1 \\
$\mathrm{~T}_{3}=1 \%$ urea at 35 days after sowing & 89.6 & 90.5 & 88.6 & 89.6 \\
$\mathrm{~T}_{4}=1 \%$ urea at 60 days after sowing & 90.2 & 92.6 & 87.2 & 90.0 \\
$\mathrm{~T}_{5}=1 \%$ urea at 85 days after sowing & 92.6 & 89.6 & 88.8 & 90.4 \\
\hline
\end{tabular}

S.E. \pm 1.5 , LSD $0.05-3.5$, LSD 0.01 - 5.1, Mean values followed by similar letters do not differ significantly at 0.05 probability level.

Table 2. Plant height $(\mathrm{cm})$ of sunflower as affected by foliar application of urea.

\begin{tabular}{ccccc}
\hline Treatments & RI & RII & RIII & Mean \\
\hline $\mathrm{T}_{1}=$ Control (no urea) & 112.3 & 98.6 & 108.6 & 106.5 \\
$\mathrm{~T}_{2}=$ Recommended urea soil applied $\left(130{\left.\mathrm{~kg} \cdot \mathrm{ha}^{-1}\right)}\right.$ & 168.9 & 161.5 & 160.6 & 163.7 \\
$\mathrm{~T}_{3}=1 \%$ urea at 35 days after sowing & 171.6 & 181.6 & 185.6 & 179.6 \\
$\mathrm{~T}_{4}=1 \%$ urea at 60 days after sowing & 172.6 & 179.6 & 181.5 & 177.9 \\
$\mathrm{~T}_{5}=1 \%$ urea at 85 days after sowing & 170.6 & 176.6 & 176.6 & 174.6 \\
\hline
\end{tabular}

S.E. \pm 4.8, LSD 0.05 - 11.1, LSD 0.01 - 16.1, Mean values followed by similar letters do not differ significantly at 0.05 probability level.

of urea on the plant height of sunflower; and there was tremendous increase in the plant height when foliar application of urea was carried out after 35 days of sowing; while the plant height decreased simultaneously with each delay in foliar application of urea. This suggested that foliar application of urea a month after sowing is more effective to improve sunflower growth as compared to delayed application of foliar urea. The LSD test suggested that the differences in plant height between foliar application of urea after 35 days, 60 days and 85 days of sowing were statistically non-significant $(\mathrm{P}>0.05)$ and significant $(\mathrm{P}<0.05)$ when compared with soil applied urea $\left(130 \mathrm{~kg} \cdot \mathrm{ha}^{-1}\right)$ and control.

Stem girth $(\mathrm{cm})$ : The data related to stem girth of sunflower as affected by foliar application of urea are given in Table 3. The analysis of variance illustrated that the effect of foliar application of urea on the stem girth of sunflower was statistically significant $(\mathrm{P}<0.05)$. It is indicated that the maximum stem girth $(5.39 \mathrm{~cm})$ was noted in sunflower crop given foliar application of urea $(1 \%)$ after 35 days of sowing, closely followed by urea foliar application after 60 days and 85 days of sowing with average stem girth of $5.34 \mathrm{~cm}$ and $5.24 \mathrm{~cm}$, respectively. In crop fertilized only by soil applied urea at $130 \mathrm{~kg} \cdot \mathrm{ha}^{-1}$ (without foliar application of urea), the stem girth decreased to $4.91 \mathrm{~cm}$; while the minimum stem girth of $3.20 \mathrm{~cm}$ was noted in plots, where urea was applied neither through soil nor in foliar form (control). There was notable and positive effect of foliar applica- 
tion of urea on the stem girth of sunflower; and stem girth improved markedly when foliar application of urea was done after 35 days of sowing; while the stem girth declined all together with each delay in foliar application of urea. This foliar application of urea a month after sowing showed most promising effect on stem girth as compared to its delayed application. The LSD test indicated that the differences in stem girth between foliar application of urea after 35 days, 60 days and 85 days of sowing were statistically non-significant $(\mathrm{P}>0.05)$ and significant $(\mathrm{P}<$ $0.05)$ when compared with soil applied urea $\left(130 \mathrm{~kg} \cdot \mathrm{ha}^{-1}\right)$ and control.

Head diameter $(\mathrm{cm})$ : The results pertaining to head diameter of sunflower as affected by foliar application of urea are presented in Table 4 . The analysis of variance indicated that the effect of foliar application of urea on the head diameter of sunflower was significant $(P<0.05)$ statistically. The maximum head diameter on average $(22.43 \mathrm{~cm})$ was recorded from the sunflower plantation given foliar application of urea (1\%) after 35 days of sowing, closely followed by foliar application after 60 days and 85 days of sowing with average head diameter of $21.89 \mathrm{~cm}$ and $21.48 \mathrm{~cm}$, respectively. In crop supplied only with soil applied urea at $130 \mathrm{~kg} \cdot \mathrm{ha}^{-1}$ (without foliar urea), the head diameter reduced to $20.13 \mathrm{~cm}$; while the lowest head diameter of $13.11 \mathrm{~cm}$ was observed in plots, where urea was applied neither through soil nor in the foliar form (control). It can be observed that there was positive and significant impact of foliar application of urea on sunflower head diameter; and this trait improved considerably when foliar application of urea was carried out after 35 days of sowing; while the head diameter was adversely affected with delay foliar application of urea. The foliar application of urea after five to six weeks after sowing proved to be more effective treatment for improving this trait as compared to delayed foliar application. The LSD test indicated that the differences in head diameter between foliar application of urea after 35 days, 60 days and 85 days of sowing were statistically non-significant $(\mathrm{P}>0.05)$ and significant $(\mathrm{P}<0.05)$ when compared with soil applied urea $\left(130 \mathrm{~kg} \cdot \mathrm{ha}^{-1}\right)$ and control.

Grains head $^{-1}$ : The results in regards to grains head ${ }^{-1}$ of sunflower as influenced by foliar application of urea are shown in Table 5 . The analysis of variance suggested that the effect of foliar application of urea on the grains head ${ }^{-1}$ of sunflower was significant $(\mathrm{P}<0.05)$ statistically. It can be seen from the results that the maximum grains head ${ }^{-1}$ (2063.25) were noted in sunflower plantation given foliar application of urea (1\%) after 35 days of sowing, closely followed by foliar application after 60 days and 85 days of sowing with 2013.65 and 1976.34 grains head ${ }^{-1}$, respectively. In crop supplied only with soil applied urea at 130 $\mathrm{kg} \cdot \mathrm{ha}^{-1}$ (without foliar urea), the grains head ${ }^{-1}$ declined to 1852.39; while the lowest grains head ${ }^{-1}$ of 849.67 were noted in plots where urea was not applied in any form (control). The results further showed that there was positive and significant effect of foliar application of urea on grains head ${ }^{-1}$ of sunflower; and this parameter improved markedly when foliar application of urea was carried out after 35 days of sowing; while the grains head ${ }^{-1}$ followed adverse trend with delay 
Table 3. Stem girth $(\mathrm{cm})$ of sunflower as affected by foliar application of urea.

\begin{tabular}{ccccc}
\hline Treatments & RI & RII & RIII & Mean \\
\hline $\mathrm{T}_{1}=$ Control (no urea) & 3.0 & 3.2 & 3.2 & 3.2 \\
$\mathrm{~T}_{2}=$ Recommended urea soil applied $\left(130 \mathrm{~kg} \cdot \mathrm{ha}^{-1}\right)$ & 5.0 & 4.8 & 4.8 & 4.9 \\
$\mathrm{~T}_{3}=1 \%$ urea at 35 days after sowing & 5.1 & 5.4 & 5.5 & 5.3 \\
$\mathrm{~T}_{4}=1 \%$ urea at 60 days after sowing & 5.1 & 5.3 & 5.4 & 5.3 \\
$\mathrm{~T}_{5}=1 \%$ urea at 85 days after sowing & 5.1 & 5.3 & 5.3 & 5.2 \\
\hline
\end{tabular}

S.E. \pm 0.1 , LSD $0.05-0.2$, LSD $0.01-0.3$, Mean values followed by similar letters do not differ significantly at 0.05 probability level.

Table 4. Head diameter $(\mathrm{cm})$ of sunflower as affected by foliar application of urea.

\begin{tabular}{ccccc}
\hline Treatments & RI & RII & RIII & Mean \\
\hline $\mathrm{T}_{1}=$ Control (no urea) & 12.5 & 13.3 & 13.3 & 13.1 \\
$\mathrm{~T}_{2}=$ Recommended urea soil applied $\left(130 \mathrm{~kg} \cdot \mathrm{ha}^{-1}\right)$ & 20.7 & 19.8 & 19.7 & 20.1 \\
$\mathrm{~T}_{3}=1 \%$ urea at 35 days after sowing & 20.1 & 23.3 & 23.8 & 22.4 \\
$\mathrm{~T}_{4}=1 \%$ urea at 60 days after sowing & 21.2 & 22.1 & 22.3 & 21.8 \\
$\mathrm{~T}_{5}=1 \%$ urea at 85 days after sowing & 20.9 & 21.7 & 21.7 & 21.4 \\
\hline
\end{tabular}

S.E. \pm 0.7 , LSD $0.05-1.7$, LSD $0.01-2.5$, Mean values followed by similar letters do not differ significantly at 0.05 probability level.

Table 5. Grains head ${ }^{-1}$ of sunflower as affected by foliar application of urea.

\begin{tabular}{ccccc}
\hline Treatments & RI & RII & RIII & Mean \\
\hline $\mathrm{T}_{1}$ = Control (no urea) & 754 & 830 & 965 & 849.6 \\
$\mathrm{~T}_{2}=$ Recommended urea soil applied $\left(130 \mathrm{~kg} \cdot \mathrm{ha}^{-1}\right)$ & 1911.8 & 1827.9 & 1817.3 & 1852.3 \\
$\mathrm{~T}_{3}=1 \%$ urea at 35 days after sowing & 1850.1 & 2147.2 & 2192.3 & 2063.2 \\
$\mathrm{~T}_{4}=1 \%$ urea at 60 days after sowing & 1953.7 & 2032.9 & 2054.3 & 2013.6 \\
$\mathrm{~T}_{5}=1 \%$ urea at 85 days after sowing & 1931.0 & 1998.9 & 1998.9 & 1976.3 \\
\hline
\end{tabular}

S.E. \pm 73.4 , LSD $0.05-169.3$, LSD $0.01-246.3$, Mean values followed by similar letters do not differ significantly at 0.05 probability level.

in foliar application of urea. This suggested that application of urea (1\%) by foliar method around $6-7$ weeks after sowing would be more effective than its delayed application. The LSD test showed that the differences in grains head ${ }^{-1}$ between foliar application of urea after 35 days, 60 days and 85 days of sowing were statistically non-significant $(P>0.05)$ and significant $(P<0.05)$ when compared with soil applied urea $\left(130 \mathrm{~kg} \cdot \mathrm{ha}^{-1}\right)$ and control.

Seed index value (1000 seeds weight $\mathrm{g}$ ): The data pertaining to seed index value of sunflower as affected by foliar application of urea are presented in Table 6. The analysis of variance indicated that the effect of foliar application of urea on the seed index value of sunflower was statistically significant $(P<0.05)$. The results indicated that the maximum seed index value $(68.51 \mathrm{~g})$ was observed in sunflower plantation given foliar application of urea (1\%) after 35 days of sow- 
ing, followed by foliar application after 60 days and 85 days of sowing with average seed index value of $64.44 \mathrm{~g}$ and $63.58 \mathrm{~g}$, respectively. In crop receiving only soil applied urea at $130 \mathrm{~kg} \cdot \mathrm{ha}^{-1}$ (no foliar application), the seed index values lightly decreased to $63.03 \mathrm{~g}$; while the minimum seed index value of $33.99 \mathrm{~g}$ were noted in plots where urea was not applied in any form (control). It is further evident from the results that the foliar application of urea was more effective to increase the on seed index value of sunflower as compared to only soil applied urea; and foliar application after 35 days of sowing was more effective to improve seed index value than its delayed application. Hence, foliar application of urea in addition to soil applied urea $\left(130 \mathrm{~kg} \cdot \mathrm{ha}^{-1}\right)$ optimized the seed index in sunflower. The LSD test showed that the differences in seed index value between foliar application of urea after 60 days and 85 days of sowing and soil application $\left(130 \mathrm{~kg} \cdot \mathrm{ha}^{-1}\right)$ were statistically non-significant $(\mathrm{P}>0.05)$ and significant $(\mathrm{P}<$ $0.05)$ when compared with foliar application after 35 days of sowing and control.

Grain yield $\left(\mathrm{kg} \cdot \mathrm{ha}^{-1}\right)$ : The results in regards to grain yield $\mathrm{ha}^{-1}$ of sunflower as affected by foliar application of urea are given in Table 7. The analysis of variance showed that the effect of foliar application of urea on the grain yield $\mathrm{ha}^{-1}$ of sunflower was significant $(\mathrm{P}<0.05)$. The results indicated that the maximum grain yield ha ${ }^{-1}(2211.90 \mathrm{~kg})$ was achieved in crop given foliar application of urea (1\%) after 35 days of sowing, followed by foliar application after 60 days and 85 days of sowing with average grain yield $\mathrm{ha}^{-1}$ of $2074.06 \mathrm{~kg}$ and $2035.63 \mathrm{~kg}$, respectively. The crop receiving only soil applied urea at $130 \mathrm{~kg} \cdot \mathrm{ha}^{-1}$ (no foliar application), resulted in $1907.96 \mathrm{~kg} \cdot \mathrm{ha}^{-1}$ grain yield; while the lowest grain yield $\mathrm{ha}^{-1}$ of $765.02 \mathrm{~kg}$ was obtained in plots where urea was applied neither as soil applied nor in foliar form (control). The results showed that foliar application of urea was markedly effective to increase grain yield $\mathrm{ha}^{-1}$ of sunflower; and foliar application of urea in addition to $130 \mathrm{~kg} \cdot \mathrm{ha}^{-1}$ soil applied urea after 35 days of sowing surpassed all other treatments including delayed foliar application. Hence, foliar application of urea in addition to soil applied urea maximized the seed yield $\mathrm{ha}^{-1}$ in sunflower. The LSD test indicated that the grain yield ha ${ }^{-1}$ showed similarity $(\mathrm{P}>0.05)$ between foliar application of urea after 60 days and 85 days of sowing and soil application $\left(130 \mathrm{~kg} \cdot \mathrm{ha}^{-1}\right)$ and differences were significant $(\mathrm{P}<0.05)$ when compared with foliar application after 35 days of sowing and control.

Oil yield $\left(\mathrm{kg} \cdot \mathrm{ha}^{-1}\right)$ : The data in pertaining to oil yield $\mathrm{ha}^{-1}$ from sunflower as affected by foliar application of urea are presented in Table 8 and the analysis of variance as Appendix-VIII. The analysis of variance indicated that the effect of foliar application of urea on the oil yield $\mathrm{ha}^{-1}$ of sunflower was significant $(\mathrm{P}<$ $0.05)$. It is obvious from the results indicated that the maximum oil yield $\mathrm{ha}^{-1}$ $(1046.75 \mathrm{~kg})$ was achieved in crop given foliar application of urea after 35 days of sowing, followed by foliar application after 60 days and 85 days of sowing with average oil yield ha ${ }^{-1}$ of $956.90 \mathrm{~kg}$ and $918.56 \mathrm{~kg}$, respectively. The crop receiving only soil applied urea at $130 \mathrm{~kg} \cdot \mathrm{ha}^{-1}$ (no foliar application), resulted in average 
Table 6. Seed index (g) of sunflower as affected by foliar application of urea.

\begin{tabular}{ccccc}
\hline Treatment & RI & RII & RIII & Mean \\
\hline $\mathrm{T}_{1}=$ Control (no urea) & 30.1 & 33.2 & 38.6 & 33.9 \\
$\mathrm{~T}_{2}=$ Recommended urea soil applied $\left(130 \mathrm{~kg} \cdot \mathrm{ha}^{-1}\right)$ & 61.1 & 63.6 & 64.2 & 63.0 \\
$\mathrm{~T}_{3}=1 \%$ urea at 35 days after sowing & 66.6 & 68.7 & 70.1 & 68.5 \\
$\mathrm{~T}_{4}=1 \%$ urea at 60 days after sowing & 62.5 & 65.0 & 65.7 & 64.4 \\
$\mathrm{~T}_{5}=1 \%$ urea at 85 days after sowing & 61.7 & 63.9 & 64.9 & 63.5 \\
\hline
\end{tabular}

S.E. \pm 1.0, LSD $0.05-2.3$, LSD $0.01-3.4$, Mean values followed by similar letters do not differ significantly at 0.05 probability level.

Table 7. Grain yield $\left(\mathrm{kg} \cdot \mathrm{ha}^{-1}\right)$ of sunflower as affected by foliar application of urea.

\begin{tabular}{ccccc}
\hline Treatments & RI & RII & RIII & Mean \\
\hline $\mathrm{T}_{1}=$ Control (no urea) & 776.6 & 854.9 & 663.5 & 765.0 \\
$\mathrm{~T}_{2}=$ Recommended urea soil applied $\left(130 \mathrm{~kg} \cdot \mathrm{ha}^{-1}\right)$ & 1969.1 & 1882.8 & 1871.8 & 1907.9 \\
$\mathrm{~T}_{3}=1 \%$ urea at 35 days after sowing & 2165.8 & 2211.7 & 2258.1 & 2211.9 \\
$\mathrm{~T}_{4}=1 \%$ urea at 60 days after sowing & 2012.3 & 2093.9 & 2115.9 & 2074 \\
$\mathrm{~T}_{5}=1 \%$ urea at 85 days after sowing & 1989 & 2058.9 & 2058.9 & 2035.6 \\
\hline
\end{tabular}

S.E. \pm 53.1, LSD $0.05-122.5$, LSD 0.01 - 178.2, Mean values followed by similar letters do not differ significantly at 0.05 probability level.

Table 8. Oil yield $\left(\mathrm{kg} \cdot \mathrm{ha}^{-1}\right)$ of sunflower as affected by foliar application of urea.

\begin{tabular}{ccccc}
\hline Treatments & RI & RII & RIII & Mean \\
\hline $\mathrm{T}_{1}=$ Control (no urea) & 316.8 & 252.8 & 223.2 & 264.3 \\
$\mathrm{~T}_{2}=$ Recommended urea soil applied $\left(130 \mathrm{~kg} \cdot \mathrm{ha}^{-1}\right)$ & 853 & 833.1 & 839.5 & 841.9 \\
$\mathrm{~T}_{3}=1 \%$ urea at 35 days after sowing & 1010.3 & 1053.8 & 1076 & 1046.7 \\
$\mathrm{~T}_{4}=1 \%$ urea at 60 days after sowing & 930.7 & 974 & 965.9 & 956.9 \\
$\mathrm{~T}_{5}=1 \%$ urea at 85 days after sowing & 907.9 & 928.9 & 918.7 & 918.5 \\
\hline
\end{tabular}

S.E. \pm 26.1 , LSD 0.05 - 60.4, LSD 0.01 - 87.8, Mean values followed by similar letters do not differ significantly at 0.05 probability level.

oil yield of $841.91 \mathrm{~kg} \cdot \mathrm{ha}^{-1}$; while the minimum oil yield ha ${ }^{-1}$ of $264.32 \mathrm{~kg}$ was obtained in control plots where neither urea through soil and nor in foliar form were applied. It is further evident from results that in addition to recommended urea $\left(130 \mathrm{~kg} \cdot \mathrm{ha}^{-1}\right)$ foliar application of urea (1\%) was highly effective to increase oil yield $\mathrm{kg} \cdot \mathrm{ha}^{-1}$; and foliar application of urea after 35 days of sowing showed superior performance over the delayed foliar spray. The LSD test showed that the oil yield $\mathrm{kg} \cdot \mathrm{ha}^{-1}$ showed similarity $(\mathrm{P}>0.05$ ) between foliar application of urea after 60 days and 85 days of sowing and differences were significant $(\mathrm{P}<$ 0.05) when compared with rest of the treatments as well as with control.

\section{Discussion}

Pakistan is deep in trouble due to shortage of edible oil production in the coun- 
try and billions of precious foreign exchange is being spent on import of edible oil for meeting the local demand. The efforts of the scientists are yet not so fruitful because the local edible oil domestic is not increasing with the pace of increasing domestic consumption of the edible oils. The reports suggested that efficient use of nitrogen fertilizer plays major role in successful crop production [6]. Foliar application of $\mathrm{N}$ in the form of urea has the advantages of low cost and rapid plant response [7]. The present study was carried out to investigate the effect of foliar applied urea on growth and yield of sunflower. The findings of the present study showed that the most effective treatment comprised of foliar application of urea (1\%) after 35 days of sowing in addition to recommended soil applied urea $\left(130 \mathrm{~kg} \cdot \mathrm{ha}^{-1}\right)$ showed optimistic results with $89.61 \%$ germination, $179.65 \mathrm{~cm}$ plant height, $5.39 \mathrm{~cm}$ stem girth, $22.43 \mathrm{~cm}$ head diameter, 2063.25 grains head ${ }^{-1}, 68.51 \mathrm{~g}$ seed index $/ 1000$ seed weight, $2211.90 \mathrm{~kg}$ seed yield ha ${ }^{-1}$ and $1046.75 \mathrm{~kg}$ oil yield $\mathrm{ha}^{-1}$. The sunflower crop receiving foliar application of urea after 60 days or 85 days of sowing in addition to recommended soil applied urea ranked $2^{\text {nd }}$ and $3^{\text {rd }}$; and sunflower plantation given no foliar urea and grown only on recommended soil applied urea $\left(130 \mathrm{~kg} \cdot \mathrm{ha}^{-1}\right)$ ranked $4^{\text {th }}$ with 1907.96 $\mathrm{kg} \cdot \mathrm{ha}^{-1}$ seed yield and $841.91 \mathrm{~kg} \cdot \mathrm{ha}^{-1}$ oil yield. However, sunflower plantation neither given foliar application of urea nor supplied with soil applied urea (control) ranked least for all the growth and yield parameters and oil yield. Hence, it is suggested for the farmers that in addition to $130 \mathrm{~kg} \cdot \mathrm{ha}^{-1}$ soil applied urea, foliar application of urea (1\%) after 35 days of sowing may be ensured for maximization of seed and oil yields in sunflower. The results further showed that in most cases, the crop receiving foliar application of urea after 60 and 85 days of sowing showed similarity $(\mathrm{P}>0.05)$; but differences were significant $(\mathrm{P}<0.05)$ when compared with foliar application after 35 days of sowing and rest of the treatments. These results are in agreement with those of many research workers. The foliar application of urea (3\%) at seed development stage added more beneficial effects to the crop performance as compared to its application and other phenological stages [9]. They applied urea as foliar application and reported beneficial effect when it was applied at seed development stage. Foliar application of $\mathrm{N}$ in the form of urea has the advantages of low cost and rapid plant response [7]. [14] suggested some 50 percent straight fertilizers for their foliar application for achieving higher sunflower yields and oil content. [15] reported that under foliar application method, the sunflower crop recorded 70.50 and 99.34 days to flowering and maturity, $214.25 \mathrm{~cm}$ plant height, $18.80 \mathrm{~cm}$ head diameter, 1877.25 seeds per head, $68.40 \mathrm{~g}$ weight of seeds per head, $42.25 \mathrm{~g}$ seed index value and $2710.00 \mathrm{~kg}$ seed yield ha ${ }^{-1}$. [16] examined the effect of foliar application of urea on sunflower and reported that foliarly applied different levels of urea tend to ameliorate the adverse effects of salt stress on both cultivars. The most effective level was $20 \mathrm{mM}$ of urea for these attributes. It was observed that the effect of salt stress and foliarly applied various levels of urea was non-significant on chlorophyll pigmentation of both cultivars. [17] investigated 
the effect of foliar and soil applied nutrients on sunflower yield and reported that the seed quality parameters improved significantly as assessed from higher seedling length $(26.67 \mathrm{~cm})$, vigour index (2230), seedling dry weight $(375 \mathrm{mg})$ and germination $(90.00 \%)$ over control. [18] examined the effect of foliar and soil applied nutrients on sunflower yield and concluded that Urea (N) as foliar spray caused seed germination of $13.50 \mathrm{~m}^{-2}$, plant height $170.50 \mathrm{~cm}$, stem girth $6.05 \mathrm{~cm}$, head diameter $28.30 \mathrm{~cm}$, number of seeds 1072.12 per head, seed weight $105.62 \mathrm{~g}$ per head, seed index $80.50 \mathrm{~g}$, seed yield $2105.75 \mathrm{~kg} \cdot \mathrm{ha}^{-1}$, harvest index $35.04 \%$ and oil content $40.55 \%$. On the basis of seed yield and oil content NPK + humic acid or when PK was given as basal dose $+\mathrm{N}$ as foliar application proved to be most effective integrated nutrient management approaches for sunflower production. [19] suggested that foliar application of nutrients could be used to improve plant tolerance to salinity by alleviating the adverse effects of salinity on growth and reproductive yield. [20] assessed that foliar application of urea (3\%) at seed development stage added beneficial effects to the crop performance in sunflower. [21] showed that there was a significant difference in interaction between concentration and foliar application stages of nitrogen on number of seeds in head. Foliar application of urea with $5 \%$ concentration in $8-10$ leaf stage had increased number of seeds per head compare to control group and other treatments about $45 \%$ and $28.27 \%$, respectively. Foliar application of nitrogen with $5 \%$ urea concentration was significantly increased grain yield compare to control treatment and urea concentration of $3 \%$ about $30.27 \%$ and $7.50 \%$, respectively.

\section{References}

[1] Ahmad, M., Rehman, A. and Ahmad, R. (2009) Oilseed Crops Cultivation in Pakistan. The Daily Dawn, Business\& Economic Review.

[2] Leland, E.F. (1996) Salinity Effect on Four Sunflower Hybrids. Agronomy Journal, 88, 215-219. https://doi.org/10.2134/agronj1996.00021962008800020016x

[3] Rathore, V.S., Gautam, R.C. and Kaushik, S.K. (2001) Yield, Quality and Nutrient Uptake by Sunflower as Influenced by Weed and Nutrient Management. Journal Annals of Agricultural Research, 22, 443-444.

[4] Hussain, T.I. and Ahmed, M.A. (2000) EM Technology-A New Looks for IPNM. In: Proceedings of the Symposium Integrated Plant Nutrient Management, NFDC, Islamabad, Pakistan.

[5] GOP. (2013) Area, Production and Yield of Cotton in Pakistan. Economic Survey of Pakistan, Government of Pakistan, Islamabad.

[6] Silberbush, L.F. (2002) Response of Maize to Foliar vs. Soil Application of Nitrogen-Phosphorus-Potassium Fertilizers. Journal of Plant Nutrition, 25, 2333-2342. https://doi.org/10.1081/PLN-120014698

[7] Oosterhuis, M. (1999) Foliar Fertilization. Beltwide Cotton Conferences, Orlando, 3-7 January 1999, National Cotton Council, Memphis, 26-29.

[8] Reisdorph, N.A. and Koster, K. (1999) Progressive Loss of Desiccation Tolerance in Germinating Pea. Pisumsativum Seeds. Physiologia Plantarum, 105, 266-271. https://doi.org/10.1034/j.1399-3054.1999.105211.x 
[9] Sharma, J.C. and Chaudhary, S.K. (2007) Vertical Distribution of Micronutrient Actions in Relation to Soil Characteristics in Lower Shivaliks of Solan District in North-West Himalayas. Journal of the Indian Society of Soil Science, 55, 40-44.

[10] Maples, R.L. and Baker, W.H. (1993) Foliar and Soil Applications of Nitrogen for Cotton during the Growing Season: In: Foliar and Soil Applications of Nitrogen for Cotton during the Growing Season: Yield Response, Arkansas Agricultural Experiment Station Special Bulletin 938, Fayetteville, 1-11.

[11] Oosterhuis, D.M. and Bondada, B.R. (2001) Yield Response of Cotton to Foliar Nitrogen as Influenced by Sink Strength, Petiole, and Soil Nitrogen. Journal of Plant Nutrition, 24, 413-422. https://doi.org/10.1081/PLN-100104969

[12] Sirko, A. and Brodzik, R. (2000) Plant Ureases: Roles and Regulation. Acta Bochimica P E, 47, 1189-1195.

[13] Blevins, D. (1989) An Overview of Nitrogen Metabolism in Higher Plants. Plant Nitrogen Metabolism Plenum, New York, 1-41. https://doi.org/10.1007/978-1-4613-0835-5_1

[14] Dev, C.M. and Sarawgi, S.K. (2004) Balance Sheet of Nitrogen, Phosphorus and Potassium as Influenced by Spacing and Nutrient Management in Sunflower, (Helianthus annuus L). Journal of Oilseeds Research, 21, 187-188.

[15] Depar, M.S., Memon, G.R., Usmanikhail, M.U., Soomro, N.A. and Baloch, F.M. (2005) Effect of Nitrogen Application Methods on the Growth and Seed Yield of Sunflower. Indus Journal of Plant Sciences, 4, 598-604.

[16] Bukhari, I. (2007) Effect of Foliar Application of Urea on Sunflower under Saline. M.Sc. Thesis, University of Agriculture, Faisalabad, 1-76.

[17] Byrareddy, B., Uppar, D.S., Vyakarnahal, B.S., Hiremath, S.M. and RaviHunje, H.L.N. (2008) Effect of Integrated Nutrient Management on Sunflower Hybrid (KBSH-I) Seed Production. Karnataka Journal of Agricultural Sciences, 21, 47-53.

[18] Kaka, A.H. (2008) To Study the Effect of Integrated Nutrient Management on Quantitative and Qualitative Characters of Sunflower. Fertilizing and Fertilizers, SAUT, 1-76.

[19] Jabeen, N. and Ahmad, R. (2012) Foliar Application of Potassium Nitrate Affects the Growth and Nitrate Reductase Activity in Sunflower and Safflower Leaves under Salinity. Notulae Botanicae Horti Agrobotanici Cluj-Napoca, 39, 172-178. https://doi.org/10.15835/nbha3926064

[20] Jat, H. (2012) Effect of Foliar Applied Urea on Growth and Yield of Sunflower (Helianthus annus L.). M.Sc. Thesis, Sindh Agriculture University Tandojam, Tandojam.

[21] Hassanlouee, M. and Baghbani, F. (2013) Effects of Stages and Amount of Nitrogen Foliar Application on Yield and Yield Components in Hybrid Alestar Sunflower. ARPN Journal of Agricultural and Biological Science, 8, 224-226. 